\title{
EFFECT OF INTERCROPPING SYSTEM AND NITROGEN FERTILIZER ON INTERCROPPED KENAF AND MAIZE
}

\author{
Sheha A.M. ${ }^{1}$, M.A.M Abd El -Daiam ${ }^{2}$ and A. M. Abou-Elela ${ }^{1}$ \\ 1-Crops Intensification Dept. ARC, Giza, Egypt, 2-Field Crops \\ Inst., ARC, Fiber Crops Res. Dep., Giza, Egypt
}

\begin{abstract}
ABSTRAC
The present investigation was carried out at the Experimental Farm of El-Gemmiza Agriculture Research Station, Agriculture Research Center, Egypt, during the two successive growing summer seasons 2013 and 2014 to study the effect of three intercropping patterns(2 ridge kenaf $(\mathrm{k}): 1$ ridge maize $(\mathrm{M}),(2 \mathrm{k}: 2 \mathrm{M})$ and $(2 \mathrm{~K}: 4 \mathrm{M})$ and three nitrogen levels $(75,105$ and $165 \mathrm{~kg}$ $\mathrm{N} /$ fed)on the productivity of maize (Three way Cross.310) and kenaf (Gize 3) The experiments were laid out in a split- plot design with three replications, three of intercropping patterns were distributed in the main plots, where, nitrogen levels were randomly allocated in the sub-plots. The main obtained results could be summarized as follows:

1- Obtained results showed that all traits of kenaf were significantly affected by intercropping system of maize with kenaf and nitrogen fertilizer, except plant height, fruting zone length, technical length and green yield/plant as compared with pure stand in both seasons. Intercropping system of $4 \mathrm{M}: 2 \mathrm{~K}$ (S3) recorded the highest values for all character, while, the lowest values were obtained from intercropping 1M:2K ( S1).

2- All characters for yield and yield components of maize were significantly affected by intercropping system and nitrogen fertilizer in the two seasons, except plant height in the first season. The highest values (14.11and13.66) were obtained from intercropping kenaf with maize on S3(4M:2K) in both seasons with hight rate of nitrogen fertilizer $\mathrm{N} 3(165 \mathrm{kgN} / \mathrm{fed}$.). Whereas lower values (11.14 and12.02 ard./fed) were obtained from intercropping system S1(2kenaf:1 maize)with lower rate on nitrogen fertilizer N1 (45kgN/fed).

3-The interactions between intercropping system and nitrogen rates of kenaf and maizet had no significant effect on all maize and kenaf characters under study in the both seasons.

4- The highest values of land equivalent ratio (LER) was1.5 in both seasons from intercropping kenaf with maize on S3(4maize:2 kenaf) under the hightest nitrogen rate $(165 \mathrm{kgN} / \mathrm{fed}$.)

5 - The highest gross return was obtained with intercropping system 4M:2K (S3) in both seasons(9250.633 and 9370.92 in the first and second seasons, resp.).

From this study it could be concluded that, the best results were kenaf was obtained by intercropping system of four ridges maize with two ridges kenaf under the highest nitrogen rate of $\mathrm{N} 3(165 \mathrm{kgN} / \mathrm{fed}$.).
\end{abstract}




\section{INTRODUCTION}

Intercropping agriculture, as defined by many researchers is growing of two or more crops simultaneously in the same land. This system helps farmers to manage more than one crop in the same field. The main reason for greater stability of yield in intercropping is that; if one crop fails, or grows poorly another companion can compensate, and such compensation cannot occur if crops are grown separately .A similar effect can occur if intercropping reduced the incidence of pests and diseases because this again could help to avoid low yield situation .Intercropping involves growing two or more crops in alternating rows on adjacent strips of variable width or in different layers (under-sown crops) on the same piece of land, during the same growing season. It thus promotes a favourable interaction between different plant species or varieties. Intercropping system, particularly involving legume crops, is considered as sound means of yield improvement for the fact that it involves integrating crops through efficient use of resources and reductions in costly inputs (Keatings and Carberry, 1993; Morris and Garrity, 1993). The most important reasons to employ intercropping is the increase in productivity per unit of land per unit time via efficient use of radiant energy and space with crops in mixture (Baldy and Stigter, 1997; Sullivan, 2003). Growing mixtures could make an important contribution, especially in risk-prone and variable environments by minimizing crop failure due to biotic and abiotic stresses and secure harvest and nutritional balance in small-scale production systems (Tilahun et al., 2005). In this regard, intercropping may be helpful for stabilization of household food supply and solve future food problems in developing countries (Beets, 1982; Tsubo et al., 2001). Kenaf (Hibiscus cannabinus L.) is an annual plant that can be useful as a source of low cost natural fibre. Itis a fast-growing plant, and can be used in the industry for a wide range of products (building materials, adsorbents, textiles, livestock feed, etc), especially for his fibre content useful for the paper production industry[ Webber and Bledsoe, 2002]. The knowledge of kenaf agronomy is important at present due to the increased number of new uses for kenaf plant. Kenaf (Hibiscuss cannabinus L.) is one of the world'smost potential sources of fiber in the cottage industry. Recently, the interest in growing kenaf has been increased throughout the world for its elevated fibercontent (Alexopoulou et al., 2000). Kenaf is a fast growing crop and has high potential to be used as anindustrial crop globally since it contains higher fibermaterials or lignocellulosic material (Manzanares et al., 1996). The seeds are goodsource of low cholesterol vegetable oil and also for biodiesel production (Webber and Bledsoe, 1993). 
Maize is one of the most important food and feed crops in Egypt for human consumption and animal feeding. Intercropping system is especially beneficial for small farmers is the low-input high risky environment of the developing areas of the world. It is perhaps the best example of how interactions between crops can be exploited to produce considerable yield benefits. Intercropping can achieve much larger yield than sole crops by using environmental resources more fully over time or more efficiently in space (Willy and Osiru 1972). Nitrogen, are considered as the major limiting factors in crop growth, development and finally economic yield (Glass, 2003). To grow kenaf the responses of plants to $\mathrm{N}$ fertilization are of considerable importance in agriculture. The objective of this investigation was to study the effect of intercropping patterns and three nitrogen levels on the productivity of kenaf (Giza 3) and maize (Three way Cross 310).

\section{MATERIALS AND METHODS}

The experiments were conducted for 2 years at the Experimental Farm of EL-Gemmiza Agriculture Research Station, Agriculture Research Center, Egypt, during the two successive growing summer seasons of 2013 and 2014. Kenaf variety Giza 3 and maize variety T WC 310.were used. The kenaf seed was sown spaced at $70 \mathrm{~cm}$ between ridges and $10 \mathrm{~cm}$ within hill while the maize were spaced at $70 \mathrm{~cm}$ between ridgs and $20 \mathrm{~cm}$ within hill. The seeds each maize and kenaf were sown per hill on plots. Both the maize and the kenaf seedling were thinned to one per stand, 3 weeks, after emergence. A split plot design with three replications was used. The experimental plot area was $12.6 \mathrm{~m}^{2}$, consisted of 6 ridges, $3 \mathrm{~m}$ long and $0.7 \mathrm{~m}$ wide. The main plots were devoted for intercropping system for kenaf and maize. Three intercropping system were as follows:

$1-1 \mathrm{M}: 2 \mathrm{~K}$ - I ridge of maize: 2 ridges of kenaf

$2-2 \mathrm{M}: 2 \mathrm{~K}-2$ ridges of maize: 2 ridges of kenaf

$3-4 \mathrm{M}: 2 \mathrm{~K}-4$ ridges of maize: 2 ridges of kenaf

4-Sole maize

5-Sole kenaf

All these arrangements gave different kenaf plant populations while the maize population remained constant. The subplots were devoted for nitrogen fertilizer. Three levels of nitrogen were used as follows:

$1-\mathrm{N}_{1}(75 \mathrm{kgN} / \mathrm{fed}$.) whereas: $45 \mathrm{~kg} \mathrm{~N} / \mathrm{fed}$.(100\%) is the recommended dose for kenaf/fed. $+30 \mathrm{~kg} \mathrm{~N} / \mathrm{fed}$.,(25\%) from recommended for maize.

$2-\mathrm{N}_{2}(105 \mathrm{kgN} / \mathrm{fed}$.) whereas: $45 \mathrm{~kg} \mathrm{~N} / \mathrm{fed}$.(100\%) the recommended for kenaf/fed+ $60 \mathrm{~kg} \mathrm{~N} / \mathrm{fed}$.(50\%) from recommended for maize. 
$3-\mathrm{N}_{3}(165 \mathrm{kgN} / \mathrm{fed}$.) whereas: $45 \mathrm{~kg} \mathrm{~N} / \mathrm{fed} .(100 \%)$ the recommended for kenaf $/ \mathrm{fed}+120 \mathrm{~kg} \mathrm{~N} / \mathrm{fed} .(100 \%)$ for recommended of maize.

Phosphorus (15.5\% P2O5) at a rate of $31.0 \mathrm{~kg} \mathrm{P} 2 \mathrm{O} 5 / \mathrm{fed}$ and potassium as potassium sulphate $(48 \% \mathrm{~K} 2 \mathrm{O})$ at a rate of $48 \mathrm{~kg}$ $\mathrm{K} 2 \mathrm{O} / \mathrm{fed}$ were applied during seedbed preparation. Nitrogen as urea $(46.6 \% \mathrm{~N})$ was applied at the above mentioned levels. It was added into three equal portions, the first third was applied prior planting, during land preparation. The second third was applied after 15 days of emergence and the rest was added at the bloom stage (40 days after emergence).Plots were weeded as needed through hand hoeing. Other normal agronomic practices for kenaf and maize production were followed.

The soil was clay in texture with $\mathrm{pH}$ of $7.3,1.2 \%$ organic matter and having $21.8,9.5$ and $520 \mathrm{ppm}$ available $\mathrm{N}, \mathrm{P}$ and $\mathrm{K}$, respectively and EC $0.8 \mathrm{millemoh} / \mathrm{cm}^{3}$.

Table (1): Planting and harvesting dates of kenaf and maize in the two seasons 2013 and 2014

\begin{tabular}{|l|l|l|l|l|}
\hline \multirow{2}{*}{ Crop } & \multicolumn{2}{|c|}{$\begin{array}{c}\text { First season } \\
2013\end{array}$} & \multicolumn{2}{c|}{$\begin{array}{c}\text { Second season } \\
2014\end{array}$} \\
\cline { 2 - 5 } & $\begin{array}{l}\text { Planting } \\
\text { date }\end{array}$ & $\begin{array}{l}\text { Harvesting } \\
\text { date }\end{array}$ & Planting date & $\begin{array}{l}\text { Harvesting } \\
\text { date }\end{array}$ \\
\hline Kenaf & $1 / 6 / 2013$ & $11 / 10 / 2013$ & $3 / 6 / 2014$ & $13 / 10 / 2014$ \\
\hline Maize & $1 / 6 / 2013$ & $1 / 10 / 2013$ & $3 / 6 / 2014$ & $2 / 10 / 2014$ \\
\hline
\end{tabular}

The other recommended agronomic practices of growing kenaf with maize were applied as recommended in maize filds.

At harvest, the maize cobs were shelled and weighed. The harvested kenaf stalks were bundled and retted in water. After retting, they were washed,sun -dried and the resultant fibre was weighed. The yields per plot were recorded and the current cash values of the two crops at the time of harvest were used in evaluating and analysing the monetary returns per fedden.

At harvest time a random sample of ten plants from each sub-plot were taken in both seasons to determine the following characters:

A- kenaf yield and its components

1- Plant height $(\mathrm{cm})$.2-fruting zone length $(\mathrm{cm})$.

3- technical length $(\mathrm{cm})$. 4-No of capsula/plant.

5-No of seeds/capsula. 6- Seed yield/capsulas (g)

7- Seed yield/fed (kg).8-green yield/plant(g)

9-green yield/fed(ton/fed). 10-fiber yield/plant(g). 11-fiber yield/fed(ton). 12-fiber percentage.

\section{The land equivalent ratio (LER)}

The land equivalent ratio (LER) was calculated for all the crop mixtures, using the following formula

\author{
B-Maize yield and its \\ components \\ 1- Plant height $(\mathrm{cm})$ \\ 2- Ear length (cm). \\ 3- 100- kernels weight $(\mathrm{g})$ \\ 4- Grain yield/plant (g) \\ 5- Grain yield/fed. (ardab).
}




$$
\begin{aligned}
& \text { LER }=\frac{y a b}{y a a}+\frac{y b a}{y b b} \\
& \text { Where: } \\
& \text { yab }=\text { yield of intercropped component a } \\
& \text { yaa }=\text { yield of solid crop a } \\
& \text { yba }=\text { yield of intercropped component } \mathrm{b} \\
& \text { ybb }=\text { yield of solid crop } \mathrm{b}
\end{aligned}
$$

\section{Statistical analysis}

Data statistically analyzed as the technique analysis of variance (ANOVA) of split- plot design as mentioned by Gomez and Gomez (1984). Treatment means were compared using the Least Significant Difference (LSD at 5\%) test as outlined by Waller (1969).

\section{RESULTS AND DISCUSSION \\ Effect of $\mathbf{N}$ fertilization levels on yield and its components of maize}

Data in Table (2) show that, increasing $\mathrm{N}$ levels had significant effect on all the studied characters in both seasons. Increasing nitrogen levels up to $165 \mathrm{~kg} / \mathrm{fed}$. produced the highest values of all studied traits for maize in both seasons. Maximum values of plant height, ear length, 100-kernels weight, grain yield /ear and grain yields/fed were observed with adding N3 (165 kg N/fed.).The increase in these characters with the increase of nitrogen level might be due to the role of nitrogen in activating the growth and yield components. These changes may positively affect LAI photosynthesis and photoassimilates effect into grain and hence increasing grain yield (Khalil et al., 2004 and Fageria, 2007). Such effects resulted in N more efficient use which, in turn, was associated with early and moderate vegetative growth along with grain yield and its attributes (Fageria and Gheyi, 1999).

Plant height: The main effects of nitrogen fertilizer on the plant height of maize were found significant (Table 2). The average plant heights ranged between 179.7 and $203.32 \mathrm{~cm}$ in first season and 204.66 and $211.22 \mathrm{~cm}$ in second seasons for nitrogen fertilizer levels. The increasing in plant height with the rise in $\mathrm{N}$ dose indicated that plants used $\mathrm{N}$ during active cell division to form building blocks (protein) for cell elongation. The performance of maize plant might be the result of residual soil fertility improved. These results are in line with those of Balasbramaniyan and Palaniappan (2001).

Ear length: Ear lengths of maize plants significantly varied depending on nitrogen fertilizer. The effect of nitrogen fertilizer levels on ear length of maize plants was positive direction and as nitrogen rates 
were increased, ear length was increase. The highest ear lengths were determined at $\mathrm{N} 3(19.93 .0 \mathrm{~cm}$ and $19.34 \mathrm{~cm})$ in the first and second seasons, respectively, and the lowest values of ear lengths of maize plants was recorded with $\mathrm{N} 1$ treatment $(18.93 \mathrm{cmand} 18.23 \mathrm{~cm})$ in the first and second seasons, respectively. The $\mathrm{N} 1$ treatment $(75 \mathrm{~kg} / \mathrm{fed}$.) was recorded the lowest values of all studied traits. The obtained results may be in line with those detected by El-Gizawy and Salem (2010) and lqbal et al. (2015).

\section{Effect of intercropping patterns on maize Yield}

The sole crop stand of maize gave significantly higher grain yield than all the crop mixture in both seasons. It was realized that the pure culture of maize afforded efficient utilization of resources since it was free of competition from other crops. It was, therefore, evident to obtain higher yield from the pure stands than in the mixed cropping.

Concerning intercropping patterns, data revealed that plant height recorded tha highest value with $S_{3}$, follwed by $S_{2}$, whereas the lost value was recorded with $S_{1}$. These results due to wide distance between maize plants and higher competition between two plants .Ear length, recorded the height value with $S_{3}$, followed by $S_{2}$, while the lowest value was recorded with $S_{1}$. On the other hand, 100-kernels weight, grain yield/ear and grain yield/fad., the highest value was recorded with $S_{3}$, followed by $S_{2}$ whereas $S_{1}$ recorded lowest value. The lower grain yield in the crop intercropped might be attributed to the effect of intercropping and plant population pressure on maize plants, because the intercrops competed well with the maize for both light and soil nutrients. These effects might have caused reduction in the real grain yield. four ridges of maize and two ridges of kenaf gave the best grain yield among the mixtures. This might have been possible because kenaf plants have tap roots that draw nutrients from higher depth than maize and thus the crops did not compete for the soil nutrients. Similar results were found by Metwally, et al (2009) and Tamiru, 2014), who found significant differences between the two intercropping patterns

The interaction of $\mathrm{N}$ fertilization level $\mathrm{x}$ intercropping pattern on all studied traits had significant effects in both seasons and in the combined data. The maximum values of plant height and ear length were recorded by the interaction of $\mathrm{N}_{1} \times \mathrm{S}_{2}$ as shown as in Table 2. On the other hand, the interaction of $N_{1} \times S_{1}$ recorded the highest 100kernels weight; grain yield/ear and grain yield/fed. in both seasons and in the combined data. However, the lowest values of grain yield/fed. were recorded from the interaction between $\mathrm{N}_{2}$ and $\mathrm{S}_{3}$. 


\section{Effect of $\mathbf{N}$ fertilizer level on yield and its components of kenaf :}

Nitrogen fertilizer significantly affected all traits of kenaf crop yield and its components under any of the three intercropping treatments in both seasons (Table3). Hovere, plant height, technical length and fruting zone length was not significant in both seasons. Plants in the N3 $(165 \mathrm{~kg} \mathrm{~N})$ was taller than the other treatments on all measured dates. Shorter plants under $\mathrm{N}$ deficiency might have been due to their effects on cell elongation as well as cell division (Roggatz et al., 1999).

\section{Effect of intercropping patterns on kenaf Yield:}

The mixture of four ridges of maize and two ridges of kenaf produced highest seed yield/fed. and seed yield/plant in both seasons(table 3 ). One ridge of maize and two ridges of kenaf produced the lowest yield of all traits in both years. The low yields in this crop arrangement suggests some sort of competition among thecrops for either light or soil nutrient since the two crops have different growth patterns. The competitive effect of maize on kenaf was drastic enough in this crop arrangement to cause low yield (Asante, 1993).

\section{Fibre yield}

Differences in grean stalk yield /fed. and fibre yields of kenaf on the intercropping pattern were significant in both seasons ,however,green stalk yield /plant and fiber percentage not significant in both seasons(Table 4).Of the mixtures, four ridges of maize and two ridges of kenaf produced highest fibre yield in both seasons with high rate of nitrogen( $\mathrm{N} 3=165 \mathrm{~kg} \mathrm{~N} / \mathrm{fed})$. One ridge of maize and two ridges of kenaf produced the lowest yield of fibre yield in both seasons under low rate of nitrogen $(\mathrm{N} 1=75 \mathrm{kgN} / \mathrm{fed})$. The low yields in this crop arrangement suggests some sort of competition among the crops for either light or soil nutrient since the two crops have different growth patterns. The competitive effect of maize on kenaf was drastic enough in this crop arrangement to cause low fibre yield (Asante 1993).

\section{Land equivalent ration (LER):}

Data in Table (5) reveald that interaction kenaf with maize increased land equivalent ratio(LER)in all intercropping tretments in the two seasons .Intercropping system 4 ridges maize:2 ridges kenaf gave the highest values for(LER)were 1.5 and 1.5 in the first and second seasons, respectively. While, Intercropping system 2 ridges maize: 2 ridges kenaf produced the lowest values of(LER)were 1.2 and1.3 in both seasons, respectively. In all intercropping treatments kenaf were more contributing than maize in both seasons The highest 
LER were determined at N3 (1.46 and1.51) in the first and second seasons, respectively, as shown as in Table 5 (Asante,1993

Economic Evalution)

\section{Gross Return:}

Data in Table(6) show that the highest total income were(L.E 9250.63 and 9370.92)in the first and second seasons, respectively, when maize was intercropped with kenaf, was obtained with $\mathrm{S} 3(4 \mathrm{M}: 2 \mathrm{~K})$ and highest level of nitrogen(N3165 $\mathrm{kg} \mathrm{N} / \mathrm{fed}$.) in both season

\section{RE FERENCES}

Alexopoulou ,E, M.Christou, M, Mardikis ,A Chatziathanassiou (2000). Growth and yield of kenaf varieties in central Greece. Ind.Crops Prod. 11: 163-172.

ASANTE, A.K. (1993).Spatial arrangement on maize and kenaf intercropping. Crops Research Institute, P.D. Box 3785, Kumasi, Ghana

Balasbramaniyan P and S.P. Palaniappan (2001). Principles and Practices of Agronomy: Integrated Farming System. Agrobios publishers. 486-489..

Baldy C, and C.J. Stigter (1997). Agrometeorology of multiple cropping in warm climates. INRA, Paris.

Beets WC (1982). Multiple Cropping and Tropical Farming Systems. Westview Press, Boulder

El-Gizawy, N.Kh.B. and H .M. Salem (2010). Influence of nitrogen sources on yield and its components of some maize varieties. World $J$. Agric. Sci., 6 (2): 218-223.

Fageria, N.K. (2007). Green measuring in crop production. J. Plant Nut.,(30):691-719.

Fageria, N.K. and H. R. Gheyi (1999). Efficient crop production Cambia Grande, P Paraiba, Brazil. Univ. of Paraiba.

Glass, A.D.M. (2003). Nitrogen use efficiency of crop plants: physiological constraints upon nitrogen absorption. Crit. Rev. Plant Sci., 22, 453-470.

Gomez, K.A. and A. Gomez (1984). Statistical Procedures of Agricultural Research. John Wiley \& Sons, New York, 2nd ed., 680p.

Iqbal, M.A., Z. Ahmad, Q. Maqsood, I.I. SHfza, and M. M. Ahmad (2015). Optimizing nitrogen level to improve growth and grain yield of spring planted irrigated maize (Zea mays L.). J. Advanced Botany \& Zoology 2: 1- 4.

Keating BA,and P.S. Carberry (1993). Resource capture and use in intercropping: solar radiation. Field Crops Res. 34:273-301.

Khalil, H.E., A.I.Nawar and A.S Kanel (2004). Response of sunflower to multi seasonal crop sequences under different regimes of NPK. Fertilization. Alex. J. Agric. Res., (49):12-23. 
Manzanares M, J.L. Tenorio and L. Ayerbe (1996). Sowing time, cultivar, plant population and application of $\mathbf{N}$ fertilizer on kenaf in Spain's central plateau. Biomass Bioenerg., 12: 263- 271.

MC.Gillchrist, C. A. (1965). Analysis of competition experiments .Biometrics ,21:975-985.

Metwally, A.A., G.O. Mohamed, M. N. Shereif and D.R.E. Abo Hegazy (2009). Yield and land equivalent ratio of intercropped corn and soybean under three intercropping patterns. 4th Conference on Recent Technologies in Agriculture.

Morris R. A. and D. P. Garrity (1993). Resource capture and utilization in intercropping: non-nitrogen nutrients. Field Crops Res. 34:319334.

Roggatz, U.,A.J. S. cdonald , I Stadenberg and U. Schurr (1999). Effects of nitrogen deprivation on cell division and expansion in leaves of Ricinus communis L. Plant Cell Environ., 22, 81-89.

Sculze, E.D. (1986). Carbon dioxide and water vapor exchange in response to drought in the atmosphere and

Sullivan P. (2003). Intercropping principles and production practices. National Center for Appropriate Technology (NCAT). ATTRA Publication. p. 135.

Tamiru, H.(2014).Effect of intercrop row arrangement on maize and haricot bean productivity and the residual soil. Global J. of Sci. Frontier Res. Agri. and Veter.14 (4)27-34

Tsubo M. S. Walker and E. Mukhala (2001). Comparisons of radiation use efficiency of mono- and inter cropping systems with different row orientations. Field crops Res. 71(1):17-29.

Waller, R.A. and D.B. Duncan. (1969). A bays rule for the symmetric multiple comparison problem. Amer. Stat. Assoc. J., 1485-1504

Webber C.L. and R.E. Bledsoe (1993). Kenaf: production, harvesting, processing and products, In: Janick J, Simon JE (Ed.): New Crops,

Webber CL and V.K. Bledsoe (2002). Kenaf yield components and plant composition. In: J.Janick and A. Whipkey (eds.), Trends in new cropsand new uses. ASHS Press, Alexandria, VA., pp. 348-357.

Webber, C. L. and V.K. Bledsoe (2002). Kenaf yield the components and plant composition. Trends in new crops and new uses. J. Janick and A. Whipkey (eds.). ASHS Press, Alexandria, VA.

Willy,R. W. and S.O. Osiru (1972). Studies on mixture of maize and beans (Phaseolus vulgaris) with particular reference to plant population. J.Sci. Cambridge 79:519-529.

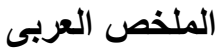

$$
\begin{aligned}
& \text { تاثير نظم التحميل و التسميد الازوتى على محصول التيلى التيل و الذرة }
\end{aligned}
$$

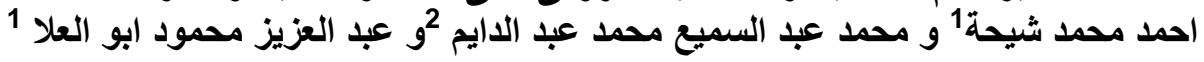

$$
\begin{aligned}
& 1 \text { - قسم بحوث التكثيف المحصولى- معهد بحوث المحاصيل الحقليةـ مركز البحوث الزراعيةـ }
\end{aligned}
$$

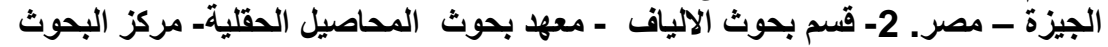

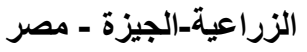




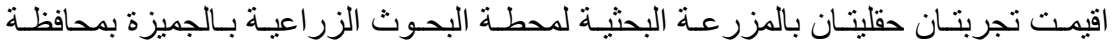

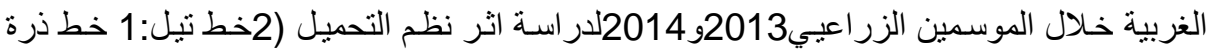

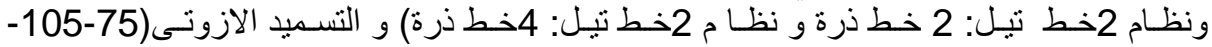

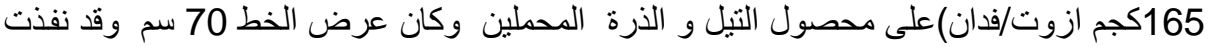

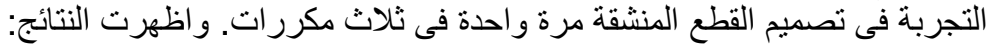

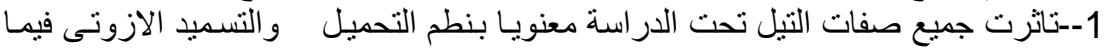

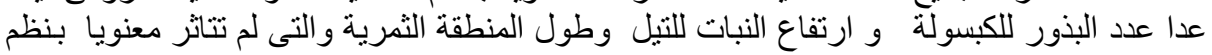

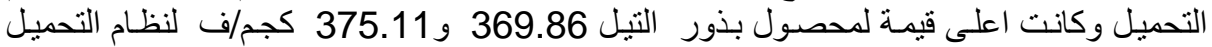

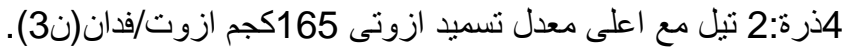

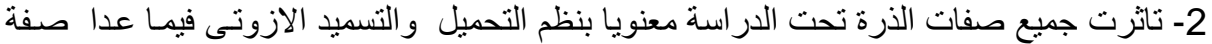

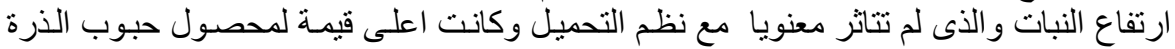

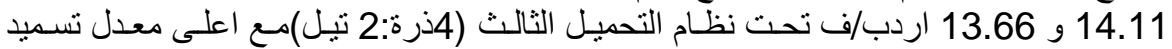

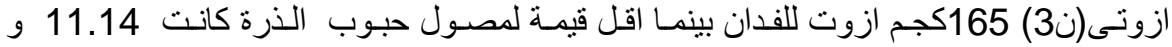

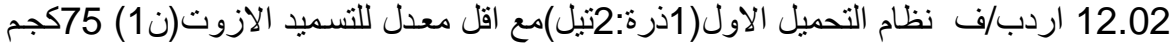
ازوت للفدان.

3- لم يتاثر التفاعل بين نظم التحميل والتسميد الازوتى معنويـا لكل صـفات التيل و الذرة تحت

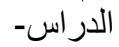

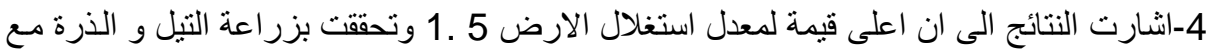

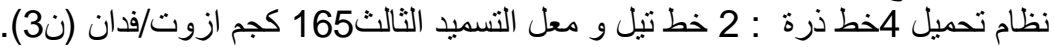

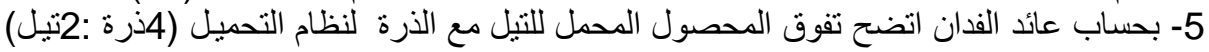

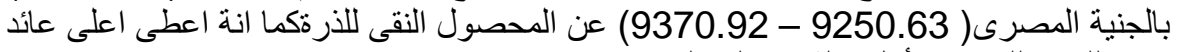

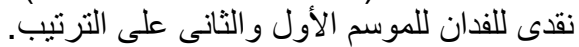

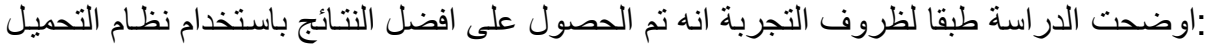

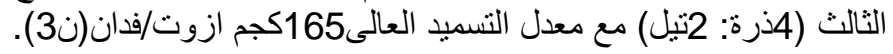

Table (2): Effects of nitrogen levels, intercropping systems and their interactions on maize yield and its components in both seasons

\begin{tabular}{|c|c|c|c|c|c|c|c|c|c|c|}
\hline Treatments & \multicolumn{2}{|c|}{ Plant height (cm) } & \multicolumn{2}{|c|}{ Ear length $(\mathrm{cm})$} & \multicolumn{2}{|c|}{ 100-kernels weight } & \multicolumn{2}{|c|}{ Grain yield/ear (g) } & \multicolumn{2}{|c|}{$\begin{array}{l}\text { Grain yield/fed } \\
\text { (ardab) }\end{array}$} \\
\hline $\begin{array}{l}\text { Intercropping } \\
\text { patterns }\end{array}$ & 2013 & 2014 & 2013 & 2014 & 2013 & 2014 & 2013 & 2014 & 2013 & 2014 \\
\hline$S_{1}$ & 181.0 & 206.556 & 19259 & 18.244 & 30.81 & 31.58 & 150.929 & 145.59 & 11.149 & 10.878 \\
\hline $\mathrm{S}_{2}$ & 200.744 & 207.667 & 19.689 & 18.533 & 31.547 & 32.376 & 153.757 & 149.41 & 13.268 & 13.889 \\
\hline$S_{3}$ & 202.244 & 210.667 & 19.744 & 19.633 & 32.713 & 33.533 & 157.53 & 151.82 & 14.111 & 14.640 \\
\hline LSD 0.05 & 44.57 & 4.52 & 0.37 & 0.35 & 1.19 & 2.03 & 23.13 & 14.35 & 1.00 & 0.772 \\
\hline & NS & NS & & & t & * & $\%$ & & ${ }^{*}$ & * \\
\hline$N_{1}$ & 179.7 & 204.667 & 18.933 & 18.233 & 30.937 & 31.589 & 145.873 & 146.74 & 12.021 & 11.964 \\
\hline $\mathrm{N}_{2}$ & 200.967 & 209.000 & 19.826 & 18.833 & 31.663 & 32.541 & 155.446 & 148.8 & 12.84 & 13.137 \\
\hline $\mathrm{N}_{3}$ & 203.322 & 211.222 & 19.933 & 19.344 & 32.47 & 33.359 & 160.897 & 151.28 & 13.667 & 14.25 \\
\hline LSD 0.05 & 35.28 & 2.604 & 1.318 & 0.262 & 0.508 & 1.241 & 12.727 & 7.183 & 0.789 & 1.100 \\
\hline & NS & & & $*$ & $\star$ & 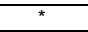 & . & & t & 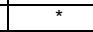 \\
\hline Interactions & NSî & NS & NS & NS & NS & NS & NS & INS & NS & NS \\
\hline LSD 0.05 & & & & & & & & & & \\
\hline solid & & & & & & & & & 21.33 & 20.85 \\
\hline
\end{tabular}

Whereas(S)intercropping system(S1 2ridges kenaf:1 maize ridge),(S2 2ridges maize:2 ridges kenaf) and $S 3(4$ ridges: 2 ridges kenaf $(N)$ nitrogen rates (N1 $75 \mathrm{kgN} / \mathrm{fed}$.,N2105kg N/fed. and N3 $165 \mathrm{~kg} \mathrm{~N} / \mathrm{fed}$. NS indicate not significant 
Table3: Yield and yield components of kenaf as affected by intercropping system, nitrogen level and interaction during 2013and2014 seasons

\begin{tabular}{|c|c|c|c|c|c|c|c|c|c|c|c|c|c|c|}
\hline \multirow{2}{*}{$\begin{array}{c}\text { Treatment } \\
\text { Intercroppin } \\
\text { g patterns }\end{array}$} & \multicolumn{2}{|c|}{$\begin{array}{c}\text { Plant } \\
\text { height }(\mathrm{cm})\end{array}$} & \multicolumn{2}{|c|}{$\begin{array}{c}\text { Fruting zone } \\
\text { length }(\mathrm{cm})\end{array}$} & \multicolumn{2}{|c|}{$\begin{array}{l}\text { Technical } \\
\text { length }(\mathrm{cm})\end{array}$} & \multicolumn{2}{|c|}{$\begin{array}{c}\text { No of } \\
\text { capsuges/plant }\end{array}$} & \multicolumn{2}{|c|}{$\begin{array}{c}\text { No of } \\
\text { Seeds/capsule } \\
\end{array}$} & \multicolumn{2}{|c|}{$\begin{array}{c}\text { Seed } \\
\text { yield/plant(g) }\end{array}$} & \multicolumn{2}{|c|}{$\begin{array}{c}\text { Seed yield/ } \\
\text { fed }(\mathbf{k g})\end{array}$} \\
\hline & 2013 & 2014 & 2013 & 2014 & 2013 & 2014 & 2013 & 2014 & 2013 & 2014 & 2013 & 2014 & 2013 & 2014 \\
\hline $\mathrm{S} 1$ & 9.89 & 3 & 34 & 1.27 & 233.5 & 238.2 & 1.89 & 44 & 1 & 39 & 8 & 23 & 4 & 349.33 \\
\hline S2 & 368.67 & 363.67 & 7.55 & 53.34 & 236.7 & \begin{tabular}{|l|}
257.4 \\
\end{tabular} & 43.33 & 42.33 & 15.56 & 14.88 & 23.11 & 24.33 & 369.33 & 355 \\
\hline S3 & 378.44 & 385.44 & 59.61 & 55.23 & 259.9 & 268.2 & 45.11 & 46.89 & 16 & 15.77 & 25.56 & 25.44 & \begin{tabular}{|l|}
375.11 \\
\end{tabular} & 369.78 \\
\hline \multirow[t]{2}{*}{ LSDat.05 } & 65.22 & 53.93 & 3.01 & 2.520 & 42.56 & \begin{tabular}{|l|}
27.89 \\
\end{tabular} & 1.805 & 2.30 & 1.11 & 1.22 & 1.26 & 0.625 & 15.52 & 6.88 \\
\hline & NS & NS & NS & NS & NS & NS & $\star$ & * & NS & NS & * & * & * & * \\
\hline N1 & 352.22 & 353.33 & 53.49 & 50.25 & 237.8 & 242.05 & 40.78 & 40.44 & 14.78 & 14.56 & 21.78 & 22.89 & 348.56 & 348.55 \\
\hline N2 & 351.67 & 363.22 & 59.09 & 53.01 & 252.1 & 250.05 & 44.22 & 43.33 & 15.67 & 15 & 23.56 & 24.22 & 359.56 & 385.55 \\
\hline N3 & 373.11 & 363.67 & 0.93 & 56.57 & 266.8 & \begin{tabular}{|l|}
268.7 \\
\end{tabular} & 45.33 & 44.98 & 16.22 & 16 & 25.11 & 25.67 & 367.78 & 367 \\
\hline \multirow[t]{2}{*}{ LSD at 0.05} & \begin{tabular}{|l|}
27.73 \\
\end{tabular} & \begin{tabular}{|l|}
37.67 \\
\end{tabular} & 5.91 & 0.333 & 40.01 & \begin{tabular}{|l|}
47.90 \\
\end{tabular} & 1.061 & 1.415 & 0.88 & 0.483 & 0.593 & 0.625 & 5.13 & 4.27 \\
\hline & NS & NS & NS & NS & NS & NS & * & * & * & 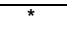 & * & & 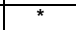 & * \\
\hline Interactions & NS & NS & NS & NS & NS & NS & NS & NS & NS & NS & NS & NS & NS & NS \\
\hline
\end{tabular}

Whereas(S)intercropping system(S1 2ridges kenaf:1 maize ridge),(S2 2ridges maize:2 ridges kenaf) and $S 3(4$ ridges: 2 ridges kenaf $(N)$ nitrogen rates $(\mathrm{N} 1$ $75 \mathrm{kgN} /$ fed.,N2105kg N/fed. and N3 $165 \mathrm{~kg} \mathrm{~N} /$ fed. NS indicate not significant

Table 4: Green stalk yield (plant and fedden), friber yield (plant and fedden) and fiber percentage of kenaf as affected by intercropping system, nitrogen level and interaction during 2013and2014 seasons

\begin{tabular}{|l|c|c|c|c|c|c|c|c|c|c|}
\hline & \multicolumn{2}{|c|}{$\begin{array}{c}\text { Green stslk } \\
\text { yield/plant(g) }\end{array}$} & $\begin{array}{c}\text { Green stslk } \\
\text { yield/fed(ton/fe } \\
\text { d) }\end{array}$ & \multicolumn{2}{c|}{$\begin{array}{c}\text { Fiber } \\
\text { yield(g/plant) }\end{array}$} & \multicolumn{2}{c|}{$\begin{array}{c}\text { Fiber } \\
\text { yield(ton/fed) }\end{array}$} & \multicolumn{2}{c|}{ percentage } \\
\hline & 2013 & 2014 & 2013 & 2014 & 2013 & 2014 & 2013 & 2014 & 2013 & 2014 \\
\hline S1 & 644.48 & 684.52 & 9.890 & 9.930 & 47.25 & 44.80 & 0.717 & 0.743 & 7.155 & 7.079 \\
\hline S2 & 655.01 & 690.01 & 10.470 & 12.660 & 47.94 & 45.81 & 0.964 & 0.944 & 6.710 & 7.014 \\
\hline S3 & 690.07 & 705.70 & 12.740 & 13.82 & 49.26 & 46.95 & 0.995 & 0.982 & 6.948 & 6.785 \\
\hline & $\mathrm{NS}$ & $\mathrm{NS}$ & ${ }^{*}$ & ${ }^{*}$ & ${ }^{*}$ & ${ }^{*}$ & ${ }^{*}$ & ${ }^{*}$ & $\mathrm{NS}$ & $\mathrm{NS}$ \\
\hline LSD at0.05 & 16.85 & 125.40 & 0.412 & 0.412 & 1.07 & 1.84 & 2.92 & 5.85 & 0.938 & 1.339 \\
\hline $\mathrm{N} 1$ & 629.53 & 679.91 & 10.480 & 11.510 & 46.89 & 43.27 & 0.861 & 0.851 & 6.823 & 6.885 \\
\hline N2 & 658.12 & 692.32 & 10.780 & 12.120 & 48.19 & 46.52 & 0.894 & 0.893 & 6.977 & 7.085 \\
\hline N3 & 690.81 & 704.00 & 11.650 & 12.730 & 49.35 & 47.77 & 0.922 & 0.927 & 7.013 & 6.909 \\
\hline & $\mathrm{NS}$ & $\mathrm{NS}$ & ${ }^{*}$ & ${ }^{*}$ & ${ }^{*}$ & ${ }^{*}$ & ${ }^{*}$ & ${ }^{*}$ & $\mathrm{NS}$ & $\mathrm{NS}$ \\
\hline LSD at0.05 & 24.61 & 78.20 & 0.457 & 0.457 & 1.41 & 1.68 & 2.29 & 2.29 & 0.031 & 1.315 \\
\hline Solid & & & & & & & 1.121 & 1.115 & & \\
\hline Interactions & $\mathrm{NS}$ & $\mathrm{NS}$ & $\mathrm{NS}$ & $\mathrm{NS}$ & $\mathrm{NS}$ & $\mathrm{NS}$ & $\mathrm{NS}$ & $\mathrm{NS}$ & $\mathrm{NS}$ & $\mathrm{NS}$ \\
\hline
\end{tabular}

Whereas(S)intercropping system(S1 2ridges kenaf:1 maize ridge),(S2 2ridges maize:2 ridges kenaf) and $\mathrm{S} 3(4$ ridges: 2 ridges kenaf $(\mathrm{N})$ nitrogen rates (N1 $75 \mathrm{kgN} / \mathrm{fed}$.,N2105kg N/fed. and N3 $165 \mathrm{~kg} \mathrm{~N} / \mathrm{fed}$. NS indicate not significant

Table (5): Land equivalent ration from yields as affected by intercropping kenaf and maize 2013 and2014 seasons

\begin{tabular}{|c|c|c|c|c|c|c|}
\hline \multirow{2}{*}{ Treatments } & \multicolumn{3}{|c|}{2013 season } & \multicolumn{3}{c|}{2014 season } \\
\cline { 2 - 7 } & Maize(LER) & Kenaf(LER) & Total(LER) & Maize(LER) & kenaf(LER) & Total(LER) \\
\hline S1 & 0.522 & 0.859 & 1.381 & 0.522 & 0.946 & 1.4 \\
\hline S2 & 0.622 & 0.639 & 1.261 & 0.666 & 0.666 & 1.3 \\
\hline S3 & 0.661 & 0.887 & 1.54 & 0.702 & 0.885 & 1.5 \\
\hline N1 & 0.563 & 0.768 & 1.33 & 0.573 & 0.693 & 1.33 \\
\hline N2 & 0.601 & 0.797 & 1.39 & 0.630 & 0.799 & 1.42 \\
\hline N3 & 0.641 & 0.822 & 1.46 & 0.683 & 0.832 & 1.51 \\
\hline
\end{tabular}


Whereas(S)intercropping system(S1 2ridges kenaf:1 maize ridge),(S2 2ridges maize:2 ridges kenaf) and $\mathrm{S} 3(4$ ridges: 2 ridges kenaf $(\mathrm{N})$ nitrogen rates (N1 $75 \mathrm{kgN} / \mathrm{fed} ., \mathrm{N} 2105 \mathrm{~kg} \mathrm{~N} / \mathrm{fed}$. and N3 $165 \mathrm{~kg} \mathrm{~N} / \mathrm{fed}$. NS indicate not significant

Table 6: Total income of kenaf and maize advantages of intercropping treatments in 2013 and 2014 seasons

\begin{tabular}{|c|c|c|c|c|c|c|c|c|}
\hline \multirow[b]{3}{*}{ Treatments } & \multicolumn{2}{|c|}{ Solid } & \multicolumn{2}{|r|}{$\mathrm{S}_{1}$} & \multicolumn{2}{|c|}{$\mathrm{S}_{2}$} & \multicolumn{2}{|r|}{$\mathrm{S}_{3}$} \\
\hline & Kenaf & Maize & kenaf & maize & kenaf & maize & kenaf & maizer \\
\hline & $\begin{array}{c}\text { Fiber } \\
\text { yield } \\
\text { Ton/fed }\end{array}$ & $\begin{array}{c}\text { Grain } \\
\text { yield/fed } \\
\text { (ardab) }\end{array}$ & $\begin{array}{l}\text { Fiber } \\
\text { yield }\end{array}$ & $\begin{array}{c}\text { grain } \\
\text { yield/fed } \\
\text { (ardab) }\end{array}$ & $\begin{array}{l}\text { Fiber } \\
\text { yield }\end{array}$ & \begin{tabular}{|c} 
Grain \\
yield $/$ \\
fed \\
$($ ardab)
\end{tabular} & $\begin{array}{l}\text { Fiber } \\
\text { yield }\end{array}$ & $\begin{array}{c}\text { grain } \\
\text { yield/fed(ardab) }\end{array}$ \\
\hline \multicolumn{9}{|c|}{2013} \\
\hline yield & 1.121 & 21.33 & 0.717 & 11.149 & 0.964 & 13.268 & 0.995 & 14.111 \\
\hline $\begin{array}{l}\text { Actual yield } \\
\text { L.E. }\end{array}$ & 5605 & 6462.99 & 3585 & 3378.14 & 4820 & 4020.204 & 4975 & 4275.633 \\
\hline $\begin{array}{l}\text { Total } \\
\text { income L.E. }\end{array}$ & 5605 & 6462 & \multicolumn{2}{|c|}{6963.14} & \multicolumn{2}{|c|}{8840.20} & \multicolumn{2}{|r|}{9250.633} \\
\hline \multicolumn{9}{|c|}{2014} \\
\hline yield & 1.115 & 20.85 & 0.743 & 10.878 & 0.944 & 13.889 & 0.987 & 14.64 \\
\hline $\begin{array}{l}\text { Actual yield } \\
\text { L.E. }\end{array}$ & 5575 & 6317.55 & 3715 & 3296.034 & 4720 & 4208.367 & 4935 & 4435.92 \\
\hline $\begin{array}{l}\text { Total } \\
\text { income L.E. }\end{array}$ & 5575 & 6317.55 & \multicolumn{2}{|c|}{7011.03} & \multicolumn{2}{|c|}{8928.37} & \multicolumn{2}{|r|}{9370.92} \\
\hline
\end{tabular}

LE 303/ ardab for maize and LE 5000 for kenaf. 